\title{
PERCEPTION OF FIRST-YEAR VERSUS SIXTH-YEAR MEDICAL STUDENTS IN SERBIA ON STUDYING MEDICINE AND POSTGRADUATE CAREER
}

\author{
Tatjana Gazibara, Ilma Kurtagić, Gorica Marić, Nikolina Kovačević, \\ Selmina Nurković, Darija Kisić-Tepavčević and Tatjana Pekmezović
}

Institute of Epidemiology, Faculty of Medicine, University of Belgrade, Belgrade, Serbia

\begin{abstract}
SUMMARY - Self-perceived stress during undergraduate medical training could influence forthcoming career choices. The aim of this study was to explore the attitudes and potential differences between $1^{\text {st }}$ and $6^{\text {th }}$ year students regarding aspects of medical training and career plans. As many as 570 students in $1^{\text {st }}$ and 400 in $6^{\text {th }}$ year of studies at the Faculty of Medicine, University of Belgrade, were recruited on December 2-9,2013. Data were acquired through a self-administered questionnaire. Students in both years rated "Helping other people" as the most important reason to study medicine. Freshmen rated statistically significantly higher 'good incomes' and 'social status' as reasons to study medicine ( $\mathrm{p}=0.003$ and $\mathrm{p}=0.037$, respectively). The most desirable fields of specialization were surgery and internal medicine (36.4\% and $18.7 \%$ for $1^{\text {st }}$ year, and $26.3 \%$ and $36.6 \%$ for $6^{\text {th }}$ year, respectively). Significantly more freshmen would prefer working abroad $\left(\chi^{2}=3.891, p=0.029\right)$. In terms of careers abroad, students in both years expressed the highest interest in working in western and northern Europe. Desires for specialty training among medical students follow the pattern of the most frequent disciplines in the Serbian physician population, with gender differences comparable to other populations. A certain percentage of students would likely emigrate.
\end{abstract}

Key words: Career choice; Students, medical; Specialization; Serbia

\section{Introduction}

Medical education in the Republic of Serbia has been entirely restructured as of 2005 according to the Bologna Process Principles ${ }^{1}$. The studies last for 6 years, with preclinical (first 3 years) and clinical (last 3 years) training, and represent the longest undergraduate studies ${ }^{2}$. After graduation, young doctors are required to work for two years before they are eligible for enrollment in specialization training that varies from 3 to 7 years depending on the discipline.

In 2010, there were 21,054 medical doctors $(36.1 \%$ male and $63.9 \%$ female) employed in health care ser-

Correspondence to: Tatjana Pekmezovic, $M D, P h D$, Institute of Epidemiology, Faculty of Medicine, University of Belgrade, Višegradska 26A, Belgrade 11000 , Serbia

E-mail: pekmezovic@sezampro.rs

Received August 25, 2014, accepted February 16, 2016 vice of the Republic of Serbia ${ }^{3}$. The number of physicians in the country, depending on the region, varied from 244 to 299 per 100,000, which is similar to the countries of the region ${ }^{4}$. Moreover, of all physicians, $15,303(72.7 \%)$ were specialists, while internal medicine, family medicine, pediatrics and gynecology/obstetrics disciplines accounted for almost half (44\%) of specialists ${ }^{3}$.

It has been observed that personal values represent the leading factor in choosing a specialty training 5 . At the same time, it seems that over the first years of undergraduate training, the idealism expressed in concerns over finances, lifestyle, further career plans and prestige of profession begins to decline ${ }^{6}$. Studies among Belgrade University students have raised several issues that are more prominent among medical as opposed to other university undergraduates. For example, one-third of males and half of females in the 
two final years of training perceived their own general stress level as moderate or high ${ }^{7}$. Besides, assessment of the health-related quality of life indicated that of all students at the University of Belgrade, medical undergraduates evaluated all the quality of life dimensions as the lowest ${ }^{8}$. Furthermore, female medical students rate their overall health status as lower than that of males ${ }^{8}$, and they appear to express more depressive symptoms ${ }^{9}$.

Although several studies have focused on medical students' health status in Serbia, there has been no evaluation of aspirations related to further career and work environment after completion of studies. Given that medical undergraduate training is longer than that in other faculties and that the level of self-perceived stress during faculty could influence career choices, the aim of this study was to explore the attitudes and potential differences between $1^{\text {st }}$ and $6^{\text {th }}$ year students regarding decision to enter undergraduate medical training, career plans and importance of particular factors associated with forthcoming employment.

\section{Subjects and Methods}

\section{Subjects}

Students of the first and the final, sixth, year were recruited at the Faculty of Medicine, University of Belgrade, before the start of compulsory practical sessions in classrooms, on December 2-9, 2013. As many as 599 persons were enrolled in the first year and 501 were enrolled in the final year of studies. After questionnaire distribution, 570 freshmen and $4006^{\text {th }}$ year students agreed to participate in the study (response rate $95.1 \%$ for $1^{\text {st }}$ year and $79.8 \%$ for $6^{\text {th }}$ year). Four investigators (SN, GM, IK and NK) introduced the study in detail to the students in classrooms. Participation in the study was anonymous. Ethical approval was obtained from the Institutional Review Board of the Faculty of Medicine, University of Belgrade.

\section{Instrument}

The questionnaire consisted of demographic characteristics (age, gender, place of residence before entering the faculty, place of current residence, and average mark obtained during studies) and questions related to the reasons for studying medicine, wishes for particular specialty training and reasons for selection of par- ticular specialty. In addition, students were asked about the size of the city/town where they would prefer working and the type of sector (public/private/both/ does not matter). Regarding potential career abroad, respondents were offered to choose whether they would prefer staying in Serbia or working abroad, the reasons for working abroad and the list of countries where they would like to work. Finally, the students were asked to rate the importance of several factors when choosing a working position. The last two questions were related to plans for postgraduate education (master, doctoral) and whether or not the students would have entered medicine if they had to choose the study again. Questions referring to the reasons for studying medicine and importance of factors when applying for job offered 8 and 6 answers, respectively, with instructions to encircle a number on 10-point scale. The mark 1 denoted "I completely disagree" and the mark 10 denoted "I completely agree" with a given statement.

\section{Data analysis}

Differences in the study variables were assessed by using Mann-Whitney U test for 2 independent samples. To assess difference in categorical variables we used $\chi^{2}$-test. Spearman's correlation test was used to investigate association between the variables. Probability value of $p<0.05$ was considered significant. The SPSS 17.0 statistical software package (SPSS Inc, Chicago, IL, U.S.A.) was used on statistical analysis.

\section{Results}

Of 970 medical students, $58.5 \%(n=570)$ were $1^{\text {st }}$ year students and $41.5 \%(n=400)$ were in the final, $6^{\text {th }}$ year. There were $35.9 \%(n=348)$ of males and $64.1 \%$ $(n=622)$ of females. The mean age among freshmen was $18.9 \pm 0.5$ years (the youngest was 18 and the oldest 23 ), and in the population of $6^{\text {th }}$ year students it was $24.7 \pm 1.7$ years (the youngest was 23 and the oldest 37 ).

The mean scores regarding reasons for studying medicine are presented in Table 1 . Students of both $1^{\text {st }}$ and $6^{\text {th }}$ years rated "Helping other people" as the most important reason to study medicine. The lowest ratings were obtained for the following reasons: "It was imposed on me" and "I did not know what else to study". However, senior students considered these assertions 
Table 1. Mean scores of reasons for studying medicine (1 - I completely disagree through 10 - I completely agree)

\begin{tabular}{|l|l|l|l|l|}
\hline Item & Variable & $\begin{array}{l}1^{\text {st }} \text { year score } \\
(\text { mean } \pm S D)\end{array}$ & $\begin{array}{l}6^{\text {th }} \text { year score } \\
(\text { mean } \pm \text { SD })\end{array}$ & p value \\
\hline 1 & Because I wanted to help others & $8.7 \pm 2.1$ & $8.4 \pm 2.4$ & 0.320 \\
2 & Because of good incomes & $6.3 \pm 2.8$ & $5.7 \pm 3.0$ & 0.003 \\
3 & Because of social status & $6.2 \pm 3.0$ & $5.7 \pm 3.1$ & 0.037 \\
4 & I have always wanted to be a doctor & $7.5 \pm 2.9$ & $7.6 \pm 2.9$ & 0.526 \\
5 & Because of my family's and friends' influence & $2.8 \pm 2.6$ & $3.2 \pm 3.0$ & 0.105 \\
6 & It was imposed on me & $1.3 \pm 1.4$ & $1.9 \pm 2.3$ & 0.004 \\
7 & I did not know what else to study & $2.4 \pm 2.6$ & $2.9 \pm 3.1$ & 0.035 \\
8 & Because medicine gives possibilities for research & $8.1 \pm 2.4$ & $7.8 \pm 2.8$ & 0.082 \\
\hline
\end{tabular}

bold values denote statistical significance

Table 2. Distribution of specialization choices of medical students in Belgrade (expressed in percentages)

\begin{tabular}{|c|c|c|c|c|c|c|c|}
\hline \multirow{2}{*}{ Item } & \multirow{2}{*}{ Specialization } & \multicolumn{3}{|c|}{$1^{\text {st }}$ year $(\%)$} & \multicolumn{3}{|c|}{$6^{\text {th }}$ year $(\%)$} \\
\hline & & $\mathrm{M}$ & $\mathrm{F}$ & Total & $\mathrm{M}$ & $\mathrm{F}$ & Total \\
\hline 1 & Surgery & 48.5 & 27.4 & 36.4 & 32.9 & 18.3 & 26.3 \\
\hline 2 & Internal medicine & 21.4 & 15.6 & 18.7 & 35.2 & 38.6 & 36.6 \\
\hline 3 & Psychiatry & 15.6 & 17.2 & 16.5 & 9.1 & 8.0 & 8.4 \\
\hline 4 & Pediatrics & 4.4 & 18.1 & 13.1 & 18.9 & 22.0 & 20.5 \\
\hline 5 & Gynecology/Obstetrics & 8.7 & 12.0 & 11.0 & 15.4 & 25.4 & 21.4 \\
\hline 6 & Forensic medicine & 10.6 & 12.2 & 10.3 & 3.5 & 10.3 & 7.7 \\
\hline 7 & Neurology & 10.2 & 8.1 & 9.0 & 19.7 & 18.5 & 18.7 \\
\hline 8 & Ophthalmology & 4.9 & 7.2 & 6.4 & 15.4 & 16.3 & 15.6 \\
\hline 9 & Pathology & 6.3 & 8.3 & 7.8 & 0.7 & 3.1 & 2.2 \\
\hline 10 & Dermatovenereology & 1.0 & 5.9 & 4.0 & 4.9 & 8.0 & 6.7 \\
\hline 11 & Infectious diseases & 5.8 & 2.2 & 3.5 & 16.9 & 10.3 & 12.3 \\
\hline 12 & Radiology & 3.5 & 3.2 & 3.3 & 14.7 & 8.4 & 10.3 \\
\hline 13 & Medical biochemistry & 2.5 & 3.1 & 2.7 & 0 & 1.2 & 0.7 \\
\hline 14 & Microbiology & 2.0 & 2.0 & 2.1 & 0 & 0.8 & 0.4 \\
\hline 15 & ENT & 1.0 & 1.7 & 1.5 & 2.1 & 4.6 & 3.6 \\
\hline \multirow[t]{3}{*}{16} & Other* & 6.0 & 4.4 & 5.3 & 9.5 & 12.1 & 10.8 \\
\hline & I did not think about specialization & 13.6 & 10.8 & 11.7 & 1.4 & 5.7 & 4.6 \\
\hline & I don't want to specialize anything & 0.5 & 0 & 0.2 & 2.8 & 0 & 0.8 \\
\hline
\end{tabular}

*Family medicine, Epidemiology, Social medicine, Pharmacology, Anesthesiology, Physical medicine and rehabilitation, Sports medicine; $\mathrm{M}=$ male; $\mathrm{F}=$ female

as significantly more dominant compared to freshmen $(\mathrm{Z}=-2.881, \mathrm{p}=0.004$ and $\mathrm{Z}=-2.105, \mathrm{p}=0.035$ respectively). Freshmen rated statistically significantly higher assertions related to "good incomes" and "social status" as reasons to study medicine $(Z=-3.023, p=0.003$ and $\mathrm{Z}=-2.085, \mathrm{p}=0.037$, respectively).
The most desirable specialization trainings in the total sample of our students were surgery and internal medicine $\left(36.4 \%\right.$ and $18.7 \%$ in $1^{\text {st }}$ year, and $26.3 \%$ and $36.6 \%$ in $6^{\text {th }}$ year, respectively) (Table 2 ). The majority of freshmen (41.8\%) and final year participants (49.2\%) would like to specialize in a particular field 
because they are "interested in it" and because they find it "dynamic and challenging".

More than half of the participants at the beginning and at the end of medical training would prefer working in a city of more than 500,000 inhabitants $(59.1 \%$ in $1^{\text {st }}$ year and $53.7 \%$ in final year). In contrast, the least proportion of students (1.9\% of freshmen and $1.7 \%$ of senior students) would like to work in a village of less than 5,000 people. Students who lived in small cities and towns before medical training expressed preference to work in smaller cities $(\rho=0.329, p=0.001)$. In addition, the majority of students $\left(39.9 \%\right.$ in $1^{\text {st }}$ year and $35.9 \%$ in $6^{\text {th }}$ year) wish to be employed in both private and public sector. However, more final year students $(27.5 \%)$ expressed willingness to work in public sector as opposed to freshmen (19.8\%).

Table 3. Distribution of reasons for working abroad (expressed as percentages)

\begin{tabular}{|l|l|l|l|l|}
\hline Item & Reason & $1^{\text {st }}$ year $(\%)$ & $6^{\text {th }}$ year $(\%)$ & p value \\
\hline 1 & Higher income & 42.0 & 44.3 & 0.248 \\
2 & Better organization of health care services & 32.5 & 34.7 & 0.258 \\
3 & Higher social status & 21.0 & 25.8 & 0.045 \\
4 & Greater opportunities for professional development & 47.9 & 38.1 & $\mathbf{0 . 0 1 0}$ \\
5 & Higher chances for immediate employment & 38.5 & 57.3 & $\mathbf{0 . 0 0 1}$ \\
\hline
\end{tabular}

bold values denote statistical significance

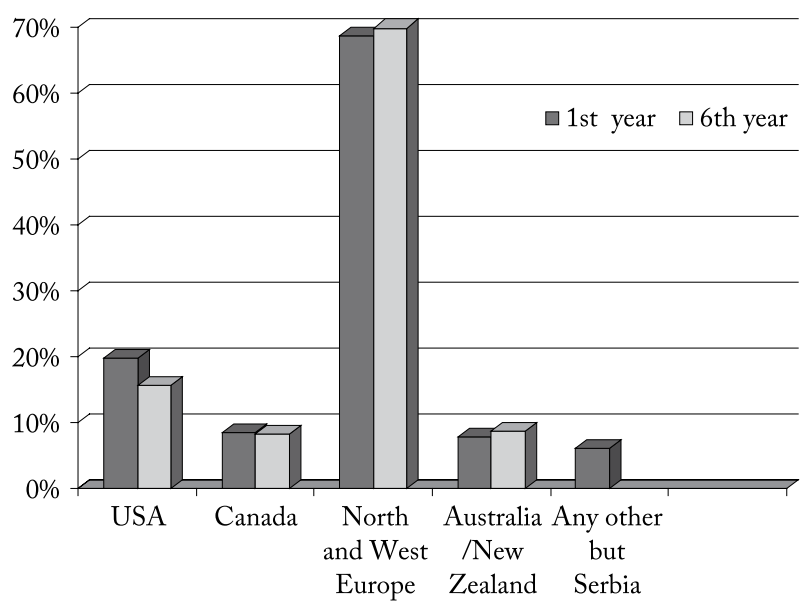

Fig. 1. Distribution of countries where medical students would like to work after graduation.
Significantly more $1^{\text {st }}$ year students would prefer working abroad $\left(\chi^{2}=3.891, p=0.029\right)$, contrary to $6^{\text {th }}$ year students who would prefer working in Serbia $\left(\chi^{2}=8.629, p=0.002\right)$. However, equal proportion of students in both years (41\%) would like to work either in Serbia or abroad. Men expressed significantly more intention to work abroad than women $\operatorname{did}\left(\chi^{2}=6.502\right.$, $\mathrm{p}=0.007)$. Distribution of reasons for working abroad is presented in Table 3. Significantly more freshmen consider that other countries offer greater opportunities for professional development $\left(\chi^{2}=9.442, \mathrm{p}=0.010\right)$. However, significantly more senior students consider that they have higher chances for employment in other countries $\left(\chi^{2}=34.499, \mathrm{p}=0.001\right)$. Distribution of countries that the students would consider working in

Table 4. Range of important factors for job choice (1 - completely disagree through 10 - completely agree)

\begin{tabular}{|l|l|l|l|l|}
\hline Item & Factor & $\begin{array}{l}1^{\text {st }} \text { year score } \\
(\text { mean } \pm \text { SD })\end{array}$ & $\begin{array}{l}6^{\text {th }} \text { year score } \\
(\text { mean } \pm \text { SD })\end{array}$ & p value \\
\hline 1 & Working hours & $6.5 \pm 2.6$ & $7.0 \pm 2.9$ & 0.001 \\
2 & Work in shifts & $6.5 \pm 2.6$ & $6.6 \pm 3.1$ & 0.035 \\
3 & Being on-call & $6.5 \pm 2.5$ & $6.6 \pm 3.1$ & 0.051 \\
4 & Level of income & $8.1 \pm 2.0$ & $8.0 \pm 2.5$ & 0.076 \\
5 & Promotion possibility & $9.1 \pm 1.6$ & $8.6 \pm 2.4$ & 0.120 \\
6 & Balance of professional and private life & $9.0 \pm 1.8$ & $8.8 \pm 2.3$ & 0.151 \\
\hline
\end{tabular}

bold values denote statistical significance 
is shown in Figure 1. Students of both years expressed highest interest in working in western and northern Europe. However, those final year students who had higher average mark were significantly more willing to work in the US $(\rho=0.117, p=0.023)$, while for other countries this association was not established.

Respondents in both years expressed that "possibilities of promotion" and "balance of professional and private life" were the most important factors when choosing a work position (Table 4). However, working hours were significantly more important for $6^{\text {th }}$ year students, along with work in shifts (Table 4). Significantly more freshmen (81.3\%) would like to enter postgraduate studies (master, doctoral) compared to $43.9 \%$ of $6^{\text {th }}$ year students of $\left(\chi^{2}=149.3, p=0.001\right)$. In addition, significantly more freshmen (93.9\%) would choose medical studies if they were to study again compared with $80.2 \%$ in $6^{\text {th }}$ year $\left(\chi^{2}=35.5, p=0.001\right)$.

\section{Discussion}

Results of our study indicated that over the course of undergraduate medical training, attitudes and career plans undergo considerable modifications. Medical students at the University of Belgrade evaluated a range of motives to enter the faculty in a divergent manner. The highest rank was obtained for altruism, i.e. willingness to help others, in both freshmen and senior students. On the contrary, the lowest rank was obtained for "being imposed on me", although senior students evaluated this particular reason as significantly more important than freshmen. In addition, reasons such as good incomes and social status were significantly more important to $1^{\text {st }}$ year students. It has been observed that students enter medical training with different motives, such as helping people, intellectual challenge, but also desire for financial compensation, prestige or pressure from parents ${ }^{10-13}$. In terms of a broad range of motives, Serbian medical students are no exemption. However, altruism appears to be a leading motive for medical training across diverse populations ${ }^{10-13}$, as well as in ours.

Regarding selection of future specialty, surgery and internal medicine were overall the most desired disciplines both at the beginning and at the end of the studies. These findings are comparable to career plans of students in Germany, where almost half of final year students planned on pursuing a career in internal med- icine, followed by specialization in surgery and family medicine ${ }^{14}$. Interestingly, family medicine was one of top choices in German medical students, while in Serbian students this discipline was not in the hotspot of students' career interest. A study in the US reports that a small proportion of students in the final year would choose to work in primary health care, which was not considered a prestigious career ${ }^{15}$. In Israel, for example, pediatrics and obstetrics/gynecology were most often considered, as opposed to anesthesiology and general surgery ${ }^{16}$. Pediatrics was the most sought after specialty in Kuwait ${ }^{17}$, whereas in the United Kingdom, a remarkable rise of trend in choosing anesthesiology, general practice and obstetrics/gynecology has been reported $^{18}$.

In addition, a change in specialty interest during undergraduate studies could be expected ${ }^{15}$. In our study, the proportion of students who would specialize in internal medicine, pediatrics, gynecology/obstetrics, neurology, ophthalmology, infectious disease and radiology rose over the course of medical studies. In contrast, the proportion of students who would specialize in surgery, psychiatry, forensic medicine and pathology decreased. This could be explained by the medical training itself. It is possible that $1^{\text {st }}$ year students have their own perception of a certain specialty before they actually start practicing it. However, after years of training, at the end of studies, it seems that only a small percentage of students would pursue specific careers.

Surgical disciplines have generally been maledominated. Although it has been suggested that male to female ratio in surgery is decreasing and that new generations seem to perceive gender equality in this discipline ${ }^{19}$, women surgeons in the US still report feeling excluded ${ }^{20}$, while the majority of medical graduates in the UK believe that surgery training does not welcome female residents ${ }^{21}$. As expected, among Belgrade medical undergraduates, males in both the first and the last year of training were more interested in surgery than females. Also, a lesser proportion of women in the final year of studies were interested in a career in surgery compared with women in the first year. Previous studies suggested that specialty choices differed between genders ${ }^{22,23}$. However, in some populations, such as in Sweden, differences in specialty preferences seem to be minor over recent years ${ }^{24}$. Overall, in terms of specialty choices, females deem 
work/time aspect and patient orientation to be more important than males ${ }^{25}$. Another social aspect in specialty choice, which was usually attributed to women, such as living with a partner, was reported to be of similar importance both to males and females in career preferences ${ }^{26}$. In choosing a work position, all of our students valued most "promotion possibility" and "balancing professional and private life", while the income level was ranked third. In contrast, final year students found working hours and work in shifts significantly more important than freshmen, which was expected considering that this student group will soon be looking for actual job. Finally, a range of available specialty trainings is also guided by the requirements of a particular health system and service ${ }^{27}$.

Considering the size of a town/city, our medical students would prefer working in a city of more than 500,000 inhabitants, indicating that they would prefer to work in the capital, Belgrade, the only city that populous in Serbia. Most students felt reluctant to work in villages, which is similar to German students ${ }^{14}$. However, in Germany, the preferred city size was that of 100,000 to 500,000 people. We found a correlation between previous living in small size cities/towns and willingness to work in such environment. However, willingness to work in rural environments seems to depend on divergent factors. Namely, in an industrialized country such as Canada, motivating factors to work in rural areas include lifestyle and finances ${ }^{28}$, while in non-industrialized countries such as Ethiopia, Ghana and Nepal, previous place of residence was the leading factor in considering rural practice ${ }^{12,29,30}$.

The majority of our students expressed willingness to work in both public and private sectors, yet a higher proportion of seniors preferred public sector compared to freshmen. In Ethiopia, for example, almost half of students prefer working in public sector, but only $6 \%$ consider private practice right after graduation ${ }^{12}$.

One of the most important issues in non-industrialized countries represents the so-called brain drain, when a significant proportion of medical graduates emigrate, usually to the US ${ }^{12,29-31}$. In Belgrade, significantly more $1^{\text {st }}$ year students seem to be interested in working abroad. It is possible that senior students feel burnout after demanding undergraduate studies and feel reluctant to take national licensing exams that most industrialized countries require. Still, almost 60\% of senior students agreed that they would get employ- ment faster abroad than in Serbia. Both freshmen and senior students considered western and northern $\mathrm{Eu}-$ ropean countries as most desirable, while the US was ranked second. Similar European regions for immigration were reported among Polish medical undergraduates $^{32}$. The possible explanation for such an immigration pattern among Serbian students is that these countries are geographically close to Serbia, and therefore visits to family and friends could be organized in an easier and more frequent manner, as opposed to living and working overseas.

Although the sample size in our survey was rather large, we did not include students from three other medical faculties in the country (Universities of Niš, Novi Sad and Kragujevac). Even though Medical Faculty in Belgrade is the largest medical school in the country, it is likely that attitudes in the capital do not reflect attitudes in the country as a whole. Our study was restricted to $1^{\text {st }}$ and $6^{\text {th }}$ year students, and therefore we were not able to make more detailed comparisons among all six study years.

This research was one of the first assessments of medical students' perceptions on forthcoming work and emigration in Serbia. Desires for specialty training among medical students in Belgrade follow the pattern of the most frequent disciplines in the Serbian physician population, with gender differences comparable to other populations. A certain percentage of students both at the beginning and at the end of medical training would likely emigrate because they consider that they would have higher chances for employment and professional development and higher income in a different environment.

\section{Acknowledgment}

The study was supported by the Ministry of Education and Science of the Republic of Serbia (grant no. 175087).

\section{References}

1. World Federation of Medical Education. Statement on the Bologna Process and medical education, 2005. Available from: http://www.aic.lv/bolona/Bologna/contrib/Statem_oth/ WFME-AMEE.pdf

2. University of Belgrade. 2013. Available from: http://www. bg.ac.rs

3. Institute of Public Health of Serbia. Health Statistical Yearbook of Republic of Serbia 2010. Available from http://www. batut.org.rs/download/publikacije/pub2010.pdf 
4. World Health Organization (WHO). Density of physicians 2011. Available from: http://www.who.int/gho/health_workforce/physicians_density/en/

5. Takeda Y, Morio K, Snell L, Otaki J, Takahashi M, Kai I. Characteristic profiles among students and junior doctors with specific career preferences. BMC Med Educ. 2013;13:125. doi: 10.1186/1472-6920-13-125

6. Morley CP, Roseamelia C, Smith JA, Villarreal AL. Decline of medical student idealism in the first and second year of medical school: a survey of pre-clinical medical students at one institution. Med Educ Online. 2013;18:21194. doi: 10.3402/meo. v18i0.21194

7. Backović DV, Živojinović JI, Maksimović J, Maksimović M. Gender differences in academic stress and burnout among medical students in final years of education. Psychiatr Danub. 2012;24(2):175-81.

8. Pekmezovic T, Popovic A, Kisic-Tepavcevic D, Gazibara T, Paunic M. Factors associated with health-related quality of life among Belgrade University students. Qual Life Res. 2011; 20(3):391-7. doi: 10.1007/s11136-010-9754-x

9. Ristić-Ignjatović D, Hinić D, Jakovljević M, Fountoulakis K, Siepera M, Rancić N. A ten-year study of depressive symptoms in Serbian medical students. Acta Clin Croat. 2013;52(2): 157-63.

10. Millan LR, Azevedo RS, Rossi E, De Marco ONL, Millan MPB, De Arruda PCV. What is behind a student's choice for becoming a doctor? Clinics (Sao Paulo). 2005;13(2):143-50.

11. McManus IC, Livingston G, Katona C. The attractions of medicine: the generic motivations of medical school applicants in relation to demography, personality and achievement. BMC Med Educ. 2006;13:11.

12. Deressa W, Azazh A. Attitudes of undergraduate medical students of Addis Ababa University towards medical practice and migration, Ethiopia. BMC Med Educ. 2012;12:68. doi: 10.1186/1472-6920-12-68

13. Kusurkar R, Ten Cate TJ, van Asperen M, Croiset G. Motivation as an independent and a dependent variable in medical education: a review of the literature. Med Teach. 2011;13: e242-62. doi: 10.3109/0142159X.2011.558539

14. Gibis B, Heinz A, Jacob R, Müller CH. The career expectations of medical students: findings of a nationwide survey in Germany. Dtsch Arztebl Int. 2012;109(18):327-32. doi: 10.3238/ arzteb1.2012.0327

15. Compton MT, Frank E, Elon L, Carrera J. Changes in U.S. medical students' specialty interests over the course of medical school. J Gen Int Med. 2008;23(7):1095-100. doi: 10.1007/ s11606-008-0579-z

16. Weissman C, Tandeter H, Zisk-Rony RY, et al. Israeli medical students' perceptions of six key medical specialties. Isr J Health Policy Res. 2013;2(1):19. doi: 10.1186/2045-4015-2-19

17. Al-Fouzan R, Al-Ajlan S, Marwan Y, Al-Saleh M. Factors affecting future specialty choice among medical students in Kuwait. Med Educ Online. 2012;17:1-7. doi: 10.3402/meo. v17i0.19587
18. Svirko E, Goldacre MJ, Lambert T. Career choices of the United Kingdom medical graduates of 2005, 2008 and 2009: questionnaire surveys. Med Teach. 2013;35(5):365-75.

doi: 10.3109/0142159X.2012.746450

19. Brown JB, Fluit M, Lent B, Herbert C. Surgical culture in transition: gender matters and generation counts. Can J Surg. 2013;56(3):153-8. doi: 10.1503/cjs.024011

20. Cochran A, Hauschild T, Elder WB, Neumayer LA, Brasel KJ, Crandall ML. Perceived gender-based barriers to careers in academic surgery. Am J Surg. 2013;206(2):263-8. doi: 10.1016/j.amjsurg.2012.07.044

21. Fitzgerald JE, Tang SW, Ravindra P, Maxwell-Armstrong CA. Gender-related perceptions of careers in surgery among new medical graduates: results of a cross-sectional study. Am J Surg. 2013;206(1):112-9. doi: 10.1016/j.amjsurg.2012.04.009

22. Vaglum P,Wiers-Jenssen J, Ekeberg O. Motivation for medical school: the relationship to gender and specialty preferences in a nationwide sample. Med Educ. 1999;33:236-42.

23. Boulis A, Jacobs J, Veloski JJ. Gender segregation by specialty during medical school. Acad Med. 2001;76:S65-7.

24. Diderichsen S, Johansson EE, Verdonk P, Lagro-Janssen T, Hamberg K. Few gender differences in specialty preferences and motivational factors: a cross-sectional Swedish study on last-year medical students. BMC Med Educ. 2013;13:39. doi: 10.1186/1472-6920-13-39

25. van der Horst K, Siegrist M, Orlow P, Giger M. Residents' reasons for specialty choice: influence of gender, time, patient and career. Med Educ. 2010;44(6):595-602. doi: 10.1111/j.1365-2923.2010.03631.x

26. Heiligers PJ. Gender differences in medical students' motives and career choice. BMC Med Educ. 2012;12:82. doi: 10.1186/1472-6920-12-82

27. Mirvis DM. Choosing a medical specialty: the difference between what students want and what society needs. Isr J Health Policy Res. 2013;2(1):18. doi: 10.1186/2045-4015-2-18

28. Jutzi L, Vogt K, Drever E, Nisker E. Recruiting medical students to rural practice: perspectives of medical students and rural recruiters. Can Fam Phys. 2009;55(1):72-3.

29. Kotha SR, Johnson JC, Galea S, et al. Lifecourse factors and likelihood of rural practice and emigration: a survey of Ghanaian medical students. Rural Remote Health. 2012;12:1898.

30. Zimmerman M, Shakya R, Pokhrel BM, et al. Medical students' characteristics as predictors of career practice location: retrospective cohort study tracking graduates of Nepal's first medical college. Br Med J. 2012;345:e4826. doi: 10.1136/bmj. e4826

31. Akl EA, Maroun N, Major S, et al. Post-graduation migration intentions of students of Lebanese medical schools: a survey study. BMC Public Health. 2008;8:191. doi: 10.1186/14712458-8-191

32. Krajewski-Siuda K, Szromek A, Romaniuk P, Gericke CA, Szpak A, Kaczmarek K. Emigration preferences and plans among medical students in Poland. Hum Resour Health. 2012;10:8. doi: 10.1186/1478-4491-10-8 


\title{
Sažetak
}

\section{STAVOVI STUDENATA PRVE GODINE U ODNOSU NA ŠESTU GODINU MEDICINE U SRBIJI PREMA STUDIJU I POSLIJEDIPLOMSKOJ KARIJERI}

\author{
T. Gazibara, I. Kurtagic, G. Marić, N. Kovačević, S. Nurković, D. Kisić-Tepavčević i T. Pekmezović
}

Stres tijekom studija medicine mogao bi utjecati na predstojeće izbore u karijeri. Svrha ovog rada bila je istražiti stavove i potencijalne razlike između studenata prve i šeste godine medicine u vezi studija i daljnjih planova u karijeri. Ukupno 570 studenata prve i 400 studenata šeste godine studija na Medicinskom fakultetu Sveučilišta u Beogradu bili su regrutirani za studiju u razdoblju od 2. do 9. prosinca 2013. godine. Podaci su dobiveni putem anonimnog upitnika. Studenti u obje godine ocijenili su "Pomaganje drugim ljudima" kao najvažniji razlog za studij medicine. Brucoši su statistički značajno više ocijenili razloge "dobri prihodi" i " socijalni status" za studij medicine ( $\mathrm{p}=0,003$ odnosno $\mathrm{p}=0,037$ ). Najpoželjnije specijalizacije bile su kirurgija i interna medicina (36,4\% odnosno $18,7 \%$ za prvu godinu i $26,3 \%$ odnosno $36,6 \%$ za šestu godinu). Statistički značajno više brucoša radije bi radili u inozemstvu $\left(\chi^{2}=3,891, p=0,029\right)$. Studenti koji bi radili u inozemstvu izrazili su najveći interes za rad u zapadnoj i sjevernoj Europi. Želje za specijalizacijom među studentima medicine slijede obrazac najčešćih disciplina među srpskim liječnicima, s rodnim razlikama kakve su prisutne i u drugim populacijama. Određeni postotak studenata vjerojatno će emigrirati.

Ključne riječi: Karijera, izbor; Studenti medicine; Specijalizacija; Srbija 